\title{
The Penetration of Fundamentalistic Principles through Sport in Conditions of Globalization?
}

\author{
Josef Oborný
}

Faculty of Physical Education and Sports Comenius University, Bratislava, Slovakia

ABSTRACT

The topic of this article unravels the dangers of penetration of fundamentalistic, political and ideological tendencies in the area of sport. It briefly analyzes the possibilities of sport abuse to realize the intention of some extremist groups. The infiltration of dangerous political attitudes to the sport is implemented through terrorism.

KEYWORDS political penetration of sport, globalization and sport, terrorism and sport, acculturation

\section{Introduction}

In the past, sport was often abused to implement the political interests of major world power structures. As an example could be given the circumstances and course of many Olympic Games of the 20th century. Looking today at this problem, we can see the light of abuse of various forms of extremism in sport. Current sport went into a complex network of connections and dependencies. It is relatively independent. But in its development we can find some political and cultural influences of the world map.

\section{Problem}

The current modern sport is, from an ideological point of view, the heir of European (Christian) culture. According to Seman (2006) modern sport became the cultural universality. Into its philosophy, naturally, the non-European elements penetrates. This phenomenon is called the concept of penetration, which may have political, religious, moral and cultural form. We believe that the sport of the 21 st century may become the Trojan horse of so-called extremist penetrations. It is known that the terrorist attacks are performed by individuals of all religious, cultural, social, educational, professional and other groups. The acts of hostility are an indirect and pessimistic prognosis of perspectives of the alliance of sport, politics, ideology and religion. 
Penetrations through sport have their own history. They are not something entirely new in the life of civilizational cultures in the world today. The history of penetration of "extremism" in the sport is long. A well-known example comes from the history of the Olympic movement. The event also received the name of the Black Shadow of the Olympic movement. This happened at the Olympic Games in Munich in 1972. Palestinian terrorists murdered 11 members of the Israeli Olympic team. At the same games two black American athletes reached the podium in the 400 meter run. On the spot they selected an unusual form of protest against the status of their race in the U.S. The IOC imposed lifetime suspensions from the Olympic Games on these athletes (Hornáček 1973). The Olympic Games are still one of the attractive potential targets of attacks by extremist groups. It is therefore necessary to continuously improve a comprehensive and integrated system to ensure the safety of the Olympic Games and sporting events (Gregor 2009, p. 186). Infiltration (alias penetration) of dangerous political attitudes in sport takes place in various forms where terrorism has a position. Terrorism is generally classified as a hazardous developmental modification of extremism. If there are root causes of terrorism, its manifestations will occur. The ideology of terrorism is "seductive" and contagious. Its application will, in our view, appear regardless of security measures in places with high concentrations of people.

Terrorist acts are often regarded as heroic deeds. This is the explanation of their promoters and executors. The global public often associates terrorism with the Islamic world, or rather with radical and fundamentalist Islamic forces. The views of one of the leaders of Islamic countries: "The heroes in the history are the individuals who made a sacrifice. ... sacrifice for those they have a relationship" (Al-Kaddáfí 1990, p. 93). He comments with scorn on sport: "Sport is like a prayer, food and warmth or cold. It is pointless, that crowd of people came to the restaurant, only to watch the man or group of people as they eat. ... Likewise, it is illogical for a society to allow an individual or team to monopolize the sport, while the people as a whole would pay expenses for a monopoly for the benefit of one person or team" (Al-Kaddáfí 1990, p. 157). The same source states that no one has the right to monopolize sport, power and wealth. Only certain institutions (eg sports clubs) do it and they are only a tool for monopolization of sport and its benefits. They are "dictatorial political tools" and they monopolize the power. Now, please focus on this quotation: "As soon as the era of the masses whisk away these tools from the world of monopolized power, wealth and weapons, it necessarily will destroy monopolies of social activities such as sports“ (Al-Kaddáfí 1990, p. 158). We did not find in the quoted book the context of sport and terrorism explicitly framed. It may also be the result, that the language of terrorism and its practical actions are different.

Causes and incentives to terrorism actually exist. For the participants it is not a problem to find the causes. It is said that man is fatally inclined to aggression and hostility. In the past, the hostility is understood as something obvious, it is said about the hostility of a priori. A peaceful life is possible only in secure borders, which is a "hostile, barbaric outside world" (Safranski 2006, pp. 29). The cited author postulates several reasons for hostility. The first is the desire for power (power is a tireless desire) or resistance to foreign powers. Another reason is the phylogenetic factor: "Man is an animal with consciousness" (Safranski 2006, pp. 30-31). Thirdly, the cause of hostility is passionate desire for diversity - "thymos". According to Plato and the tradition of Platonic thinking it is a mental strength and it is demonstrated in the courageous action by which an individual wants to demonstrate his superiority and honor - a man overcomes self-preservation by thymotic passion. "Thymotic passion is even able for intensify a life to risk an ordinary life" (Safranski 2006, pp. 31-32).

Examples from recent days suggest that we are not far from the truth. "What we previously only supposed, we now know. In Hungary, there are men prepared to commit terrorist acts, as the newspaper Népszabadság was told by the director of the National Security Office, Sándor Laborcz, 
who estimated the number of potential terrorists in the dozens. Slightly higher in number are the extremists, whose hard core may start armed attacks on the democratic state establishment. As an example, Laborcz cited four members of the National Liberation Army, The Arrows of Hungarians, who were arrested earlier this month. According to the Budapest press, the arrested men prepared attacks using bombs hidden in footballs, of which five had been produced (Laborcz 2009).

The same problem in another geographic area: Internet sources reported that 12 Pakistani children died in a bomb explosion. They confused the bomb with a toy. The tragedy occurred in the restive border region in northwest Pakistan. "Seven of the children belonged to one family. Among them were five girls," said a police representative in the Malakand region of North West Frontier Province. The bomb, which was similar to a football, was found by the kids near a local school. They began to play with the unusual object and it suddenly exploded. It is unclear whether this was a deliberate act of terrorism, or just a random incident. The area is dotted with unexploded ordnance of the Mujahideen, who in the 1980s fought against Soviet troops in neighboring Afghanistan (Pakistan, 2009).

Marked, but also other forms of terrorism are the element of the most important contemporary process - globalization. Processes of globalization are beyond the control of the states, they are "managed" with a kind of invisible hand. Most sports clubs in top-level sport are also "multinational" companies. They are controlled by the "global" culture - impersonal, often hostile, harsh, aggressive. Management structures of extremist movements often present their activities as a protest against globalization and against the unfair distribution of wealth that globalization produces. What is concrete?

In the context of globalization it is necessary to remember the problem of acculturation and exchange of cultural values. It is also necessary for the reason that sport is generally regarded as an important element of global and national culture (Gomez 2009, p. 22). It is characterized as a phenomenon of culture and civilization. One of the features of globalization is the process of promoting the universalisation of values. The economic and political values wil be transmitted on the waves of globalization and they represent the most powerful forces of globalization. Usually it's the values that are typical of the current political powers. However, there is no evidence "that the birth of powerful global communications brings an attitude and a greater convergence of views" (Huntington 2001, p. 54). People understand that the global spread of values and information through membership of a civilization is therefore understood differently.

Global exchange of sport values need not be carried out by acculturation. It may not even take place at all. When we look at the problem from a general point of view we have an argument in hand. Western culture "is threatened" by the danger that comes from immigrants from other societies who refuse to assimilate and continue to maintain and emphasize the values, customs and culture of their home societies" (Huntington 2001, p. 372). Moreover, there is one circumstance. Entertainment (a sports show), which sweeps the world and has a similar spread of sports culture, though not the same as the conversion or exchange of cultural values. If a sport is fun then it is true that the sport and information about the sport cannot possibly be clearly considered as a means of global value conversion or acculturation. Various forms of sport shows are an attractive audience, but nevertheless under-valued. It is cheap entertainment indicated by the media as an "industry of substitutional (quasi) pleasure". It is known that many fundamentalist movements are very faint or have even a negative attitude towards sport and entertainment, which is tied to the sport.

Consider the problem in terms of sports migration. "Immigrants" in the destination country as bearers of sports talent also generate the sports value and excellent athletes. Today, they are largely assimilated with the culture of a new home and looking for a new form of identity. Already based on 
past experience, however, they assume that it will increase their need to retain the original cultural and religious identity. Assimilation and identity are different and even contradictory processes. Global, cultural harmony of civilization still has not had its time. There is a view that dangerous conflicts of the future are likely to emerge from the Western arrogance, Islamic intolerance, and China's assertiveness (Huntington 2001, p. 213). We believe that the migration of athletes from "non-western countries" (with the aim of receiving the values of the physical nature) to the western countries will also be marked by this phenomenon. Migration of athletes for more favorable conditions for sports and living standards has two sides. In terms of positive thinking it may mean desirable acculturation, enriching of cultural sites of the athlete's lifestyle and of his sports life. At the same time it can mean the proportion of sport as a cultural phenomenon on the nationwide acculturation. The "sign" of "positive" acculturation is respect and empathy of the cultural identity of a community, prior to his values. This distinguishes the acculturation in the cultural assimilation.

The values of sport have on the one side a human, universalistic breath, on the other side national cultural aspect, social mission and personal dimension. On the territory constituted by the global sports the current world cultures meet through athletes and individuals involved in its organization and through various kinds of sports. In relation to the individualities and to the values that they represent, however, the sports world is marked by idolatria (worship of idols such as voodoo, idolatry). This is about money. Money became the unifying phenomenon of the multicultural world of sport.

\section{Conclusion}

Sport offers a proposal for the formulation and solution of many global issues. It offers as a problem the existence of so-called irreconcilable differences between different cultures and shows possible solutions through the spontaneity of processes of globalization. Existing cultural diversity in sport transforms the mutual enrichment of cultures. It outlines many of the solutions to social, civilizational and cultural problems of global nature. Misuse of any sport on behalf of ideals is aimed against its ethos, which is a deep, spiritual, moral, and humanistic sense of the value of sport and activities of people active in sport (Oborný 2007, p. 206). Sport itself is not inherently linked to terrorism, but some elements of the system are appropriated for the political atavism. Sporting events provide "excellent" conditions for terrorist actions - many people in a small space, mass media publicity, multicultural structure of the participants, the planned nature of events and others. But in sport itself, we can find the elements of aggression, which are very similar to an act of terrorism. These elements penetrate into the sport not only of political life, but also of normal civic life.

\section{REFERENCES}

Al-Kaddáfí, M. (1990). Zelená kniha /Green Paper/. Praha: Dialog. ISBN 80-85194-11-2.

Black Power Movement (2009). Retrieved from http://law.jrank.org/pages/4776/Black-Power-Movement.html. (Date site visit: 2. 4. 2009).

Gomez, R. (2009). Sport and Globalisation: Homogenization and Differentiation. In Physical Culture and Sport. Studies and Research, vol XLVII. Warsaw: Versita. ISSN 1899-4849 (Online) DOI: 10.2478/v10141-009-00287.

Gregor, T. (2009). Terorizmus ako ohrozenie bezpečnosti a životov občanov /Terrorism as a threat to the safety and lives of citizens/. In Gregor, T. (Ed.) Šport a spoločenské a humanitné vedy 2009 /Sport and social and humanities sciences/. (CD- ROM). Bratislava: ICM AGENCY. ISBN 978-80-89257-14-0.

Hornáček, I. (1973). Sapporo - Mníchov 1972. Bratislava : Smena. 
Huntington, S. P. (2001). Střet civilizací. Boj kultur a proměna světového řádu /The Clash of Civilizations. Fight the culture and the transformation of world order/. Praha: Rybka Publishers. ISBN 80-86182-49-5.

Laborcz, S. (2009). Retrieved from http://spravy.pravda.sk/v-madarsku-sa-objavil-politicky-terorizmus fet/sk_svet.asp?c =A090427_081256_sk_svet_p12. (Date site visit: 28. 4. 2009).

Nordhaus, W. (2009). Retrieved from http://econoir.blogspot.com/2008/04/ekonomick-glbus.html. (Date site visit: 28.4 .2009$)$

Oborný, J. (2007). Étos (éthos) športu (encyklopedické heslo) / Ethos of Sport/. In J. Kasa \& Š. Švec (Eds.). Terminologický slovnik vied o športe /Terminological Dictionary of Sport Science/. Bratislava: Univerzita Komenského \& Fakulta telesnej výchovy a športu. ISBN 978-80-89197-78-1.

Pakistan (2009). Retrieved from http://tvnoviny.sk/spravy/svet/deti-si-pomylili-bombu-s-hrackou.html. (Date site visit: 28. 4. 2009)

Safranski, R. (2006). Kol’ko globalizácie unesie človek? /Wieviel Globalisierung verträgt der Mensch?/. Bratislava: Kalligram. ISBN 80-7149-858-8.

Seman, F. (2006). Moderný šport a moderný olympizmus /Modern sports and modern olympizmus/. In Kasa \& Š. Švec et al. Štruktúra poznatkovej bázy vied o športe /The structure of the knowledge base of Sport Science/. Bratislava: Univerzita Komenského \& Fakulta telesnej výchovy a športu. ISBN 978-80-89197-65-1. pp. 256263. 